\title{
A CASE OF POST-OPERATIVE HYPOPARATHYROIDISM
}

Ps KUMAR, MI KESTON JONES 
ㅁ 41 yr old woman,Total Thyroidectomy-2007 for large MNG

口 Post op-Hypocalcaemic with low PTH

口 Treated with high dose alpha-calcidol therapy and Ca supplements-suboptimal response

口 Improved response with Teriparatide

口 No other relevant drug history 


\section{Investigations}

口 Serum magnesium-normal

口 Corrected serum calcium levels in the six months preceding Teriparatide-1.71 to 1.93 $\mathrm{mmol} / \mathrm{L}$

口 Corrected serum calcium in the six months post Teriparatide- 1.96 to $2.10 \mathrm{mmol} / \mathrm{L}$ 


\section{Current Treatment}

ㅁ Teriparatide-20 micrograms s/c daily

ㅁ Alpha-calcidol-4 to 15 micrograms od; currently 8 micrograms od

ㅁ Thyroxine - 200 micrograms od 


\section{Conclusions \& Discussion}

口 Post-op Hypoprathyroidism - 1 to $4 \%$ following thyroid surgery for hyperthyroidism

口 Treatment -high dose alpha-calcidol, occasionally recombinant human parathyroid hormone,either Teriparatide(1-34) or intact hormone Preotact(1-84)

口 Recombinant human PTH achieves normocalcaemia,is more effective at preventing osteoporosis,allows reduction in dose of calcium and alpha calcidol

口 Of the 1000 patient members of Parathyroid UK,7 are on Teriparatide and 1 is on Preotact.16 members received Preotact during REPLACE PTH 1-84 Clinical Trial in 2010(plus some non members)

口 Problems of supply,funding, licensing:costs comparable: Preotact gave better results in USA: Results from REPLACE PTH(Lancet $7 / 10 / 2013$ ) suggest that 50,75 or 100 microgram of rhPTH(1-84) administered s $\mathrm{C}$ in outpt setting is efficacious and well tolerated as a PTH replacement therapy 